Original Research Paper

\title{
Influence of Different Freezing Curves on the Acrosome Integrity of Male Goat Sperm Cells
}

\author{
Sofia Alexandra Fagundes Lopes, Henrique José Duarte Rosa, \\ António Chaveiro and Fernando Moreira da Silva* \\ IITAA-Institute of Agricultural and Environmental Research and Technology/Faculty of Agricultural and Environmental \\ Sciences, University of the Azores, Rua Capitão João d'Avila, 9700-042, Angra do Heroísmo, Portugal
}

\author{
Article history \\ Received: $12-11-2020$ \\ Revised: 15-01-2021 \\ Accepted: 18-02-2021 \\ Corresponding Author: \\ Fernando Moreira da Silva \\ IITAA-Institute of Agricultural \\ and Environmental Research \\ and Technology/Faculty of \\ Agricultural and Environmental \\ Sciences, University of the \\ Azores, Rua Capitão João \\ d'Avila, 9700-042, Angra do \\ Heroísmo, Portugal \\ Email: joaquim.fm.silva@uac.pt
}

\begin{abstract}
The aim of the present study was to evaluate the effect of three different freezing curves on male goat's sperm viability and acrosome integrity. Semen was collected on three adult male goats in February (Azores, Portugal, latitude $38^{\circ} 39^{\prime} \mathrm{N}$ ) using an artificial vagina and a female with induced heat. Three collection sessions were spaced of approximately 5 days. The study followed a factorial design of repeated measurements. After volume, sperm concentration and mass motility evaluation, live and dead spermatozoa (spz) were counted and acrosome integrity was evaluated by Flow Cytometry (FCM). In the meantime semen was frozen using three curves differing in the second cooling ramp rate (curve $\mathrm{A}=25^{\circ} \mathrm{C} / \mathrm{min}$, curve $\mathrm{B}=35^{\circ} \mathrm{C} / \mathrm{min}$ and curve $\mathrm{C}=45^{\circ} \mathrm{C} / \mathrm{min}$ ). After thawing, the percentage of live/dead sperm cells and the acrosome integrity were determined by FCM, using respectively Propidium Iodide (PI) and Pisum Sativum Agglutinin conjugated to Fluorescein Isothiocinate (FITC-PSA). By combining these two fluorochromes, the thawed semen was divided into: Live sperm with intact acrosome, unstained PI and unstained FITC-PSA (LL); live sperm with damaged acrosome, unstained PI and stained FITC-PSA (LR); dead sperm with intact acrosome, stained PI and unstained FITC-PSA (UL); dead sperm with damaged acrosome, stained PI and stained FITC-PSA (UR). Although different freezing curves did not significantly influence live sperm rate with intact $(19.14 \pm 0.86 \%$ spz curve A, $17.72 \pm 0.86 \% \mathrm{spz}$ curve $\mathrm{B}$ and $18.18 \pm 0.86 \% \mathrm{spz}$ curve C) or damaged $(0.44 \pm 0.04 \%$ spz curve A, $0.38 \pm 0.04 \%$ spz curve B and $0.49 \pm 0.04 \%$ spz curve C) acrosome, a significant $(\mathrm{P}<0.05)$ effect of animals was observed in the four parameters studied. Regarding the percentage of LL spermatozoa, buck 1 presented values lower $(\mathrm{P}<0.05)$ by about $50 \%$ than bucks 2 and 3 . Data also were affected significantly by the day of collection. These results strongly suggest that although goat sperm cells are not influenced by the pattern of cooling curves investigated, a considerable variability in the response of individual animals as well as the collection date may be expected.
\end{abstract}

Keywords: Male Goat Semen, Freezing Curves, Freezing Rates, Cryopreservation

\section{Introduction}

The success of mammalian semen cryopreservation depends upon many factors (Purdy, 2006), including interactions among cryoprotectants, type of extender, cooling rate, thawing rate and packaging, as well as variation among individual animals (Cotter et al., 2005). Over the last decades various freezing procedures have been tested in different animal species, including goats (Küçük et al., 2014; Yodmingkwan et al., 2016;
Salmon et al., 2017) aimed to minimize detrimental effects of cryopreservation on parameters like sperm motility, viability, morphology, plasma membrane or acrosome integrity. Thus, the freezing rate used is an important criterion throughout this process, since sperm dehydration is faster with slower freezing rates and forms more ice ridges with faster freezing rates (Kumar et al., 2003). In general, the spermatozoa of goat are much more sensitive to cryopreservation when compared to other domestic species. Additionally, the 
cryopreservation of goat semen is very challenging since its plasma includes high concentration of the enzyme phospholipase which hydrolyzes lecithin from milk and the egg yolk-most common components of cryopreservation diluents-into fatty acids and lysolecithins, thus affecting sperm viability (Leboeuf et al., 2000; Purdy, 2006). These particular characteristics of male goat semen requires an extended attention to maximize the post-thawing sperm viability.

In this context, the main objective of the present study was to test the effect of three different cooling curves on the post-thawing integrity of male goat acrosome sperm cell without removing the seminal plasma during the cryopreservation process.

\section{Materials and Methods}

\section{Semen Collection}

The collection of semen was carried out in the Agrarian Development Services of Terceira Island (SDAT), in 3 male goats (Saanen) with 2 years of age. The collections were performed during February in 3 sessions 5 days apart. Semen collection was obtained with artificial vagina after the bucks were trained for about 3 weeks using an induced estrus female with intramuscular injection of $250 \mu \mathrm{g}$ of estradiol benzoate diluted in $2.5 \mathrm{~mL}$ of mineral oil applied $48 \mathrm{~h}$ before the time set aside for collection. Twenty-four hours after the onset of estrus, estradiol benzoate was again injected at a dose of $100 \mu \mathrm{g}$. The collections were always carried out in the morning starting around 08:00 A.M. and in each collection day the male goats alternated randomly. The artificial vagina used contained water heated to $48-50^{\circ} \mathrm{C}$ and the collection tubes were preheated to $33-36^{\circ} \mathrm{C}$. The transport of the semen to the laboratory was done in a thermal box with water at $33-36^{\circ} \mathrm{C}$.

\section{Evaluation of Semen}

Immediately after arriving the laboratory, the semen was placed in a water bath at $36^{\circ} \mathrm{C}$ and then evaluated for volume, concentration and mass motility. The volume was quantified by micropipetting and mass motility, assessed by placing a drop of $5 \mu \mathrm{L}$ of pure semen on a slide preheated at $36^{\circ} \mathrm{C}$ in the microscopic, heated stage and observed under an optical microscope at a magnification of $100 \mathrm{x}$ in several microscopic fields, This mass sperm motility was scored subjectively from 0 (no motion) to 5 (numerous rapid waves) on a scale with steps equal to 1 according to the original method described by (Evans and Maxwell, 1987). Only ejaculates with more than $70 \%$ motility (score 4 and 5) were evaluated and cryopreserved. Sperm concentration was determined by counting through the Neubauer chamber, diluting $10 \mu \mathrm{L}$ of pure semen in $990 \mu \mathrm{L}$ of distilled water, at a magnification of $400 \mathrm{x}$.

\section{Dilution of Fresh Semen}

The semen samples were diluted to give a final concentration of $400 \times 10^{6} \mathrm{spz} / \mathrm{ml}$. The diluent used was based on egg yolk and prepared only in a fraction. To achieved this, the following compounds were added: 375 $\mathrm{mM}$ Tris, $124 \mathrm{mM}$ citric acid, $41.6 \mathrm{mM}$ glucose, $9 \%(\mathrm{v} / \mathrm{v})$ egg yolk and $5 \%(\mathrm{v} / \mathrm{v})$ glycerol by adjusting the $\mathrm{pH}$ to 6.8 (Atessahin et al., 2008). After the dilution to fill the straws, the spermatozoa were counted alive/dead, as well as the evaluation of the acrosome integrity, staining the semen with Propidium Iodide (PI) and Pisum Sativum Agglutinin conjugated to Fluorescein Isothiocinate (FITC-PSA).

\section{Freezing of Semen}

After dilution and filling of the straws, they were cooled in a styrofoam box in the refrigerator at $4^{\circ} \mathrm{C}$ for $2 \mathrm{~h}$ and 30 min. The freezing of semen was carried out with an automatic freezer (IceCube 14S; SyLab, Austria), placing the straws in a horizontal support, where it was frozen according to 3 curves, each with three cooling ramps. Two cooling ramps, i.e., between -4 and $-5^{\circ} \mathrm{C}$ (decreasing temperature of $4^{\circ} \mathrm{C} / \mathrm{min}$ ) and between -110 and $-140^{\circ} \mathrm{C}$ (decreasing temperature of $35^{\circ} \mathrm{C} / \mathrm{min}$ ) were common to the three curves. The third cooling ramp, i.e., between -5 and $110^{\circ} \mathrm{C}$, differed among curves in its decreasing rate of temperature $\left(25,35\right.$ and $45^{\circ} \mathrm{C} / \mathrm{min}$ respectively for curves 1 , 2 and 3 ) which really marked the difference among curves.

\section{Post-Thaw Evaluation}

The thawing of semen in straws followed the methodology proposed by Evans and Maxwell (1987), i.e., the placement of straws in a water bath at $37^{\circ} \mathrm{C}$ for 2-3 $\mathrm{min}$ and analysed by $15 \mathrm{~min}$. The post-thawing semen evaluation was performed by flow cytometry with Propidium Iodide (PI) and Pisum Sativum Agglutinin conjugated to Fluorescein Isothiocinate (FITC-PSA), as described by Franco et al. (2013), determining the living and dead spermatozoa with intact or damaged acrosome. A suspension was prepared with $20 \mu \mathrm{L}$ of thawed semen $\left(400 \times 10^{6} \mathrm{spz} / \mathrm{ml}\right)$ and $160 \mu \mathrm{L}$ of PBS, from which $5 \mu \mathrm{L}$ $\left(50^{\circ} 10^{6} \mathrm{spz} / \mathrm{ml}\right)$ was withdrawn and $495 \mu \mathrm{L}$ of a solution was added to the cytometer. The latter solution was prepared with $4 \mathrm{~mL}$ of PBS and two fluorescent labels, these being the PI and SYBR-14, with 10 and $4 \mu \mathrm{L}$ respectively, incubated in the dark for $15 \mathrm{~min}$ and then read on the cytometer. To determine the percentage of live spermatozoa and with the intact acrosome, the cytometer was used again. First, the straws were thawed (one per sample) in a water bath at $37^{\circ} \mathrm{C}$ for $30 \mathrm{sec}$. Three well-identified tubes were then placed in the oven at $37^{\circ} \mathrm{C}$ for each dose of thawed semen. One of these tubes was used to place the thawed semen sample, another to dilute and the last to be taken to the cytometer for evaluation. Dilution was done in an Eppendorf tube 
with $10 \mu \mathrm{L}$ of thawed semen in $990 \mu \mathrm{L}$ PBS. Then 295 $\mu \mathrm{l}$ of this solution was withdrawn and $6 \mu \mathrm{L}$ of PI $(0.5$ $\mathrm{mg} / \mathrm{ml}$ ) and $20 \mu \mathrm{L}$ of FITC-PSA were added, then incubated in the oven at $37^{\circ} \mathrm{C}$ for $10 \mathrm{~min}$. Finally, 600 $\mu \mathrm{L}$ of PBS was placed and evaluated on the cytometer.

\section{Statistical Analysis}

The experiment followed a factorial repeated measures design model ( 3 freezing curves $\times 3$ bucks $\times 3$ days of semen collection). According to this model, the effects of freezing curve, buck and semen collection day upon the post-thawing semen parameters were tested by repeated measures factorial ANOVA considering the freezing curve and buck as between subjects factors and the semen collection day as the within-subject variable. The means of fresh semen parameters evaluated macroscopically (volume, concentration and motility) were compared by one-way ANOVA. When ANOVA detected significant differences within the variables studied, a multiple-comparison test (Fisher's post hoc Protected Least-Squares Differences-PLSD) was followed to identify these differences. All percentages were previously transformed according to the formula $P^{\prime}$ $=\operatorname{arcosen} \sqrt{ } P$ where $P$ represents the original value. However, for clarity, data in tables and throughout the text are the originals. All tests were performed using the IBM $^{\circledR}$, Armonk, NY, USA SPSS software v. 24.

\section{Results}

Data concerning macroscopy sperm evaluation are reported in Table 1. The global spermatic concentration of the fresh semen was $3.36 \pm 1.3 \times 10^{9} \mathrm{spz} / \mathrm{ml}$ and the volume of fresh semen was $0.79 \pm 0.14 \mathrm{~mL}$. For any of these parameters no significant differences were observed between male goats. Regarding mass motility, the mean active sperm ratio was $79.02 \pm 5.40 \%$ (ranging from points 4 to 5 according to Evans and Maxwell, 1987) and the sperm viability assessed by flow cytometry was $(42.36 \pm 5.66 \%$ of live epz). Again, no significant difference was observed between the different male goats.

It was observed that, after thawing, $18.78 \pm 0.9 \%$ spermatozoa were classified as alive, of which $97.7 \%$ had intact acrosome (LL) and only $2.3 \%$ had damaged acrosome (LR) (Table 2).

The different freezing curves used did not present significant differences concerning live spz with either intact or damaged acrosome (Table 2).

Significant differences were observed among different male goats $(\mathrm{P}<0.001)$ and days of collection $(\mathrm{P}$ $<0.002)$ relative to live spermatozoa with intact acrosome after thawing (Table 3). In relation to the live $\mathrm{spz}$ but with the damaged acrosome, differences $(\mathrm{P}=$ 0.016 ) were observed between male goats 1 and 2 $(0.55 \pm 0.04$ and $0.31 \pm 0.04 \%$, respectively).

Table 1: Mean \pm standard error of the parameters evaluated in fresh sperm from different male goats. The observed differences were not statistically significant $(\mathrm{P}>0.05)$

\begin{tabular}{llll}
\hline Male goat & Volume $(\mathrm{ml})$ & Concentration $\left(\times 10^{9} \mathrm{spz} / \mathrm{ml}\right)$ & Mass motility* \\
\hline 1 & $0.72 \pm 0,28$ & $5.08 \pm 1,38$ & $73.3 \pm 6,67$ \\
2 & $0.75 \pm 0,08$ & $2.05 \pm 0,34$ & $86.25 \pm 2,25$ \\
3 & $0.89 \pm 0,07$ & $2.98 \pm 0,90$ & $77.5 \pm 2,50$ \\
Mean & $0.79 \pm 0.14$ & $3.36 \times 10^{9} \pm 1.3$ & $79.02 \pm 5.40$ \\
\hline
\end{tabular}

*Mean active sperm ratio

Table 2: Mean \pm standard error of percentages of live spz with intact acrosome (\% spz LL); alive with damaged acrosome (\% spz LR); dead with intact acrosome (\% spz UL) and dead with damaged acrosome (\% spz UR) as influenced by the different freezing curves. The observed differences were not statistically significant $(\mathrm{P}>0.05)$

\begin{tabular}{lllll}
\hline Curves & \% spz LL & \% spz LR & \% spz UL & \% spz UR \\
\hline A & $19.14 \pm 0.86$ & $0.44 \pm 0.04$ & $11.64 \pm 0.63$ & $68.78 \pm 1.39$ \\
B & $17.72 \pm 0.86$ & $0.38 \pm 0.04$ & $11.36 \pm 0.63$ & $70.54 \pm 1.39$ \\
C & $18.18 \pm 0.86$ & $0.49 \pm 0.04$ & $10.37 \pm 0.63$ & $70.96 \pm 1.39$ \\
\hline
\end{tabular}

Table 3: Mean \pm standard error of percentages of live spz with intact acrosome (\% spz LL); alive with damaged acrosome (\% spz LR); dead with intact acrosome (\% spz UL) and dead with damaged acrosome (\% spz UR) by animal and collection day

\begin{tabular}{lllll}
\hline & $\%$ spz LL & $\%$ spz LR & $\%$ spz UL & $\%$ spz UR \\
\hline Animal & & & & \\
$\mathbf{1}$ & $10.97 \pm 0,86^{\mathrm{a}}$ & $0.55 \pm 0,04^{\mathrm{a}}$ & $5.64 \pm 0,63^{\mathrm{a}}$ & $82.84 \pm 1,39^{\mathrm{a}}$ \\
$\mathbf{2}$ & $23.10 \pm 0,86^{\mathrm{b}}$ & $0.31 \pm 0,04^{\mathrm{b}}$ & $13.57 \pm 0,63^{\mathrm{b}}$ & $63.01 \pm 1,39^{\mathrm{b}}$ \\
$\mathbf{3}$ & $20.96 \pm 0,86^{\mathrm{c}}$ & $0.45 \pm 0,04^{\mathrm{ab}}$ & $14.16 \pm 0,63^{\mathrm{b}}$ & $64.43 \pm 1,39^{\mathrm{b}}$ \\
Mean & $18.34 \pm 3.74^{\mathrm{b}}$ & $0.43 \pm 0.07$ & $11.12 \pm 2.75$ & $70.09 \pm 6.39$ \\
Collection day & & & $11.02 \pm 0,87^{\mathrm{ab}}$ & $63.31 \pm 1,13^{\mathrm{a}}$ \\
$\mathbf{1}$ & $25.33 \pm 0,66^{\mathrm{a}}$ & $0.33 \pm 0,03^{\mathrm{a}}$ & $9.12 \pm 0,43^{\mathrm{a}}$ & $72.09 \pm 0,64^{\mathrm{b}}$ \\
$\mathbf{2}$ & $18.40 \pm 0,66^{\mathrm{b}}$ & $0.40 \pm 0,03^{\mathrm{ab}}$ & $13.23 \pm 0,82^{\mathrm{b}}$ & $74.87 \pm 1,39^{\mathrm{b}}$ \\
$\mathbf{3}$ & $11.31 \pm 0,91^{\mathrm{c}}$ & $0.59 \pm 0,08^{\mathrm{b}}$ & $11.12 \pm 1.19$ & $70.09 \pm 3.48$ \\
\hline Mean & $18.35 \pm 4.05$ & $0.44 \pm 0.08$ & &
\end{tabular}

Within the same column, means sharing the same letter are not significantly different $(\mathrm{p}<0.05)$ 
After thawing, the male goat factor had an influence on the percentage of dead spermatozoa $(\mathrm{P}<0.001)$. Regarding the day of collection factor, it was observed that there were only significant differences $(\mathrm{P}<0.05)$ between days $2(9.12 \% \pm 0.43)$ and $3(13.23 \% \pm 0.82)$ in the percentage of dead spz with intact acrosome (Table 3 ).

\section{Discussion}

The global spermatic concentration of the fresh semen obtained in this study is in agreement with the results of de Oliveira et al. (2009). However, the volume of fresh semen was slightly higher, possibly due to the fact that the fresh semen collections was made with a longer time interval, which allowed the bucks to reestablish seminal production. Mass motility, is in agreement with the results obtained by Salmon et al. (2017). However, the sperm viability assessed by flow cytometry was lower than that published by others, (Salmon et al., 2017; de Oliveira et al., 2009; Oliveira et al., 2011; Garner and Johnson, 1995).

After thawing, the semen was evaluated in order to observe the influence of the freezing curves on the spermatozoa relative to the live/dead and the acrosome integrity (intact or damaged). The values obtained are in agreement with the results observed by Salmon et al. (2017) in the group in which the influence of seminal plasma in the freezing process without another additive in the cryoprotective medium was studied.

The different freezing curves used in the present study did not affect significantly the percentage of live spz with either intact or damaged acrosome. Barbas et al. (2005), also used two freezing curves with different temperatures in the second ramp in sheep semen collected throughout the year and observed significantly higher rates $(\mathrm{P}<0.001)$ of normal spz in the summer and autumn in one of the curves. Bag et al. (2002) performed a similar study with sheep, using a freezing rate of $25^{\circ} \mathrm{C} / \mathrm{min}$ in the freezing of the semen, but with different initial temperatures. In the present study, the cooling temperature was the same in the three curves and the only difference was the freezing rate, namely 25,35 and $45^{\circ} \mathrm{C} / \mathrm{min}$. Üstüner et al. (2015) developed a similar work in which male goat semen was frozen according to four different freezing rates between +5 and $-150^{\circ} \mathrm{C}$, having a lowering temperature between 10 and $24^{\circ} \mathrm{C} / \mathrm{min}$ which showed a significant detrimental effect on sperm post-thawing motility and acrosome integrity, although not affecting the integrity of sperm DNA. However, this experiment allowed the authors to discover that procedures related to dilution, equilibration time and thawing had negative effects on acrosome motility and integrity of spz. These effects were also observed in the studies of Barbas and Mascarenhas (2009) and Dorado et al. (2009) who showed that sperm from small ruminants, such as male goats, do not have high adaptability to temperature changes, which may contribute to the sensitivity of spermatozoa. Frankel et al. (2013) observed significantly better results for faster freezing rates $\left(40^{\circ} \mathrm{C} / \mathrm{min} \mathrm{Vs} 10^{\circ} \mathrm{C}, 20^{\circ} \mathrm{C}\right.$ and $\left.30^{\circ} \mathrm{C} / \mathrm{min}\right)$.

Male goats and days of semen collection influenced the proportion of live spermatozoa with intact acrosome after thawing. According to Üstüner et al. (2015), the success of cryopreservation depends not only on the freezing rates used, but also on factors such as species and breed. Since animals of different species and individually, have different sperm membrane composition, different rates of freezing, cholesterol/phospholipids and saturation levels of the carbohydrate chain, may affect the way spermatozoa react to cooling and, subsequently, confer different sensitivities to cryopreservation (Medeiros et al., 2002).

The male goat and day of collection factors also affected the percentage of dead spermatozoa. According to Oettle (1986), most spermatic lesions in the acrosome occur during the dilution, cooling or as a result of the equilibrium period to which the semen is subjected. In this way, it is important to optimize the initial processing of the semen, allowing the great majority of spermatozoa to reach the process of freezing-thawing without changes in the acrosome and, therefore, with greater chances of surviving unharmed in the freezing process.

\section{Conclusion}

The main objective of this study was to evaluate the effect of three different freezing curves on the percentage of live sperm, with or without acrosome damage, of male goat semen. The results were very similar for the 3 curves and the differences, of about 2 to $3 \%$, were not statistically significant. Although the number of replicates (9) appeared reasonable at the beginning of the experiment, a relatively high variability (coefficient of variation of around 14\%) occurred mainly due to the significant effect of the animal and the day of semen collection which could have masked the results. In this view, the detection of a significant influence of both the animal and the day of collection of the semen can be an alert for the need to redouble the attention to give to these two factors. The results of the present study seem to suggest the absence of a substantial effect of the pattern of freezing curves tested on the post-thaw percentage of live sperm of male goat semen.

Considering that the distinction of the freezing curves tested only focused on the second cooling ramp and in a low accentuated manner (temperature difference of $10^{\circ} \mathrm{C}$ ), 
it is suggested for further research to test curves with wider cooling differences and/or applied to different ramps.

\section{Acknowledgement}

The authors deeply thank the DRDA (Terceira Island-Azores) for all facilities during collecting semen in their goats. IITAA (University of the Azores) is also fully acknowledged. This project was financed in $85 \%$ by FEDER and in $15 \%$ with regional funds through the "Programa Operacional Açores 2020 (Operational Program Azores 2020), in scope of the project CryotecACORES-01-0145-FEDER-000092".

\section{Author's Contributions}

Sofia Alexandra Fagundes Lopes: Performed the experiments and was involved in manuscript writing.

Henrique José Duarte Rosa, António Chaveiro and Fernando Moreira da Silva: Designed the experiment and were responsable for manuscript writing.

Henrique José Duarte Rosa and Sofia Alexandra Fagundes Lopes: Field experiment and statistical procedures.

\section{Ethics}

This article is original and contains unpublished material. The corresponding author confirms that all authors have read and approved the manuscript and no ethical issues arise. The animals were handled in accordance with the best animal welfare procedures.

\section{References}

Atessahin, A., Bucak, M. N., Tuncer, P. B., \& Kızıl, M. (2008). Effects of anti-oxidant additives on microscopic and oxidative parameters of Angora goat semen following the freeze-thawing process. Small Ruminant Research, 77(1), 38-44. https://doi.org/10.1016/j.smallrumres.2008.03.002

Bag, S., Joshi, A., Naqvi, S. M. K., Rawat, P. S., \& Mittal, J. P. (2002). Effect of freezing temperature, at which straws were plunged into liquid nitrogen, on the post-thaw motility and acrosomal status of ram spermatozoa. Animal Reproduction Science, 72(3-4), 175-183. https://doi.org/10.1016/S03784320(02)00118-5

Barbas, J. P., \& Mascarenhas, R. D. (2009). Cryopreservation of domestic animal sperm cells. Cell and Tissue Banking, 10(1), 49-62. https://doi.org/10.1007/s10561-008-9081-4

Barbas, J. P., Baptista, C. C., \& Horta, A. E. M. (2005). Comparison of two freezing methods for Merino Regional and Serra da Estrela ram semen. Revista Portuguesa de Ciencias Veterinarias, 553, 61.
Cotter, P. Z., Goolsby, H. A., \& Prien, S. D. (2005). Preliminary evaluation of a unique freezing technology for bovine spermatozoa cryopreservation. Reproduction in Domestic Animals, 40(2), 98-99. https://doi.org/10.1111/j.1439-0531.2004.00540.x

de Oliveira, R. V., Nunes, J. F., Salgueiro, C. D. M., Cavalcante, J. M. M., Moura, A. D. A., \& de Araújo, A. A. (2009). Morphologic evaluation of goat spermatozoa diluted and frozen in media based on powder coconut water (PCW-101) or TRIS, stained by eosin-nigrosin and bromophenol blue. Ciência Animal Brasileira, 10(3), 862-869. https://www.cabdirect.org/cabdirect/abstract/201030 14259

Dorado, J., Hidalgo, M., Muñoz, A., \& Rodríguez, I. (2009). Assessment of goat semen freezability according to the spermatozoa characteristics from fresh and frozen samples. Animal Reproduction Science, 112(1-2), 150-157. https://doi.org/10.1016/j.anireprosci.2008.04.005

Evans, G., \& Maxwell, W. C. (1987). Salamons' artificial insemination of sheep and goats (No. Ed. 2). Butterworths. https://www.cabdirect.org/cabdirect/abstract/198901 69622

Franco, J. S. V., Chaveiro, A., Góis, A., \& da Silva, F. M. (2013). Effects of $\alpha$-tocopherol and ascorbic acid on equine semen quality after cryopreservation. Journal of Equine Veterinary Science, 33(10), 787-793. https://doi.org/10.1016/j.jevs.2012.12.012

Frankel, T. E., Theisen, D. D., Guthrie, H. D., Welch, G. R., \& Woods III, L. C. (2013). The effect of freezing rate on the quality of striped bass sperm. Theriogenology, 79(6), 940-945. https://doi.org/10.1016/j.theriogenology.2013.01.009

Garner, D. L., \& Johnson, L. A. (1995). Viability assessment of mammalian sperm using SYBR-14 and propidium iodide. Biology of Reproduction, $53(2)$, 276-284. https://doi.org/10.1095/biolreprod53.2.276

Küçük, N., Aksoy, M., Uçan, U., Ahmad, E., Naseer, Z., Ceylan, A., \& Serin, I. (2014). Comparison of two different cryopreservation protocols for freezing goat semen. Cryobiology, 68(3), 327-331. https://doi.org/10.1016/j.cryobiol.2014.04.009

Kumar, S., Millar, J. D., \& Watson, P. F. (2003). The effect of cooling rate on the survival of cryopreserved bull, ram and boar spermatozoa: a comparison of two controlled-rate cooling machines. Cryobiology, 46(3), 246-253. https://doi.org/10.1016/S0011-2240(03)00040-3 
Leboeuf, B., Restall, B., \& Salamon, S. (2000). Production and storage of goat semen for artificial insemination. Animal Reproduction Science, 62(1-3), 113-141. https://doi.org/10.1016/S03784320(00)00156-1

Medeiros, C. M. O., Forell, F., Oliveira, A. T. D., \& Rodrigues, J. L. (2002). Current status of sperm cryopreservation: why isn't it better? Theriogenology, 57(1), 327-344. https://doi.org/10.1016/S0093-691X(01)00674-4

Oettlé, E. E. (1986). Changes in acrosome morphology during cooling and freezing of dog semen. Animal Reproduction Science, 12(2), 145-150. https://doi.org/10.1016/0378-4320(86)90054-0

Oliveira, R. V., Nunes, J. F., Salgueiro, C. C. M., Cavalcante, J. M. M., Brasil, O. O., \& Moura, A. A. A. N. (2011). Evaluation of goat spermatozoa frozen in media based on powder coconut water media based (ACP-101®) or TRIS. Arquivo Brasileiro de Medicina Veterinária e Zootecnia, 63(6), 1295-1302. https://doi.org/10.1590/S0102-09352011000600003
Purdy, P. H. (2006). A review on goat sperm cryopreservation. Small Ruminant Research, 63(3), 215-225. https://doi.org/10.1016/j.smallrumres.2005.02.015

Salmon, V. M., Leclerc, P., \& Bailey, J. L. (2017). Novel technical strategies to optimize cryopreservation of goat semen using cholesterolloaded cyclodextrin. Cryobiology, 74, 19-24. https://doi.org/10.1016/j.cryobiol.2016.12.010

Üstüner, B., Nur, Z., Alcay, S., Toker, M. B., Sağirkaya, H., \& Soylu, M. K. (2015). Effect of freezing rate on goat sperm morphology and DNA integrity. Turkish Journal of Veterinary and Animal Sciences, 39(1), 110-114. https://doi.org/10.3906/vet-1407-70

Yodmingkwan, P., Guntaprom, S., Jaksamrit, J., \& Lertchunhakiat, K. (2016). Effects of extenders on fresh and freezing semen of boer goat. Agriculture and Agricultural Science Procedia, 11, 125-130. https://doi.org/10.1016/j.aaspro.2016.12.021 